\title{
IMPACT OF PRE-IRRADIATION ON THE MAGNETIC SUSCEPTIBILITY OF Cz-Si THERMALLY TREATED AT 700-1000 ${ }^{\circ} \mathrm{C}$
}

\author{
V. M. Tsmots ${ }^{1}$, P. G. Litovchenko ${ }^{2}$, Yu. V. Pavlovskyy ${ }^{1,2}$, O. P. Litovchenko ${ }^{2}$, \\ I. S. Pankiv ${ }^{1,2}$, M. M. Luchkevych ${ }^{1,2}$ \\ ${ }^{1}$ Solid-State Microelectronics Laboratory of NASU and MONU \\ at the Ivan Franko Drohobych State Pedagogical University, \\ 36 Franko Str., Drohobych, 82100, tsmots@drohobych.net \\ ${ }^{2}$ Institute of Nuclear Research of NASU, 47 Nauky avenue, Kyiv \\ IMPACT OF PRE-IRRADIATION ON THE MAGNETIC SUSCEPTIBILITY \\ OF Cz-Si THERMALLY TREATED AT 700-1000 ${ }^{\circ} \mathrm{C}$ \\ V. M. Tsmots, P. G. Litovchenko, Yu. V. Pavlovskyy, O. P. Litovchenko, \\ I. S. Pankiv, M. M. Luchkevych
}

\begin{abstract}
Dependence of paramagnetic component of silicon magnetic susceptibility on pre-irradiation by fast neutrons (fn) after subsequent thermal treatment of samples at $700-1000{ }^{\circ} \mathrm{C}$ has been studied. It has been shown based on the measurements of magnetic susceptibility that the value of the paramagnetic component arising after the said thermal treatment of silicon is influenced by up to $10^{18} \mathrm{fn} / \mathrm{cm}^{2}$ pre-irradiation. With the increase of the irradiation rate this impact decreases significantly. Probable mechanisms of defect creation explaining the discovered peculiarity are discussed.
\end{abstract}

Keywords: silicon, oxygen, magnetic susceptibility, irradiation, thermal treatment

\section{ВПЛИВ ПОПЕРЕДНЬОГО ОПРОМІНЕННЯ НА МАГНІТНУ СПРИЙНЯТЛИВІСТЬ Cz-Si, ТЕРМООБРОБЛЕНОГО ПРИ 700-1000 ${ }^{\circ} \mathrm{C}$}

\section{В. М. Цмоць, П. Г. Литовченко, Ю. В. Павловський, О. П. Литовченко,} І. С. Паньків, М. М. Лучкевич

Анотація. Досліджено залежності парамагнітної складової магнітної сприйнятливості (MC) кремнію від дози попередньо опромінення швидкими нейтронами (fn), після послідуючої термообробки зразків при $700-1000^{\circ} \mathrm{C}$. На основі результатів вимірювання магнітної сприйнятливості показано, що на величину парамагнітної складової, яка виникає після зазначених термообробок кремнію, суттєво впливає попереднє опромінення дозами до величини порядку $10^{18} \mathrm{fn} / \mathrm{cm}^{2}$. При подальшому збільшенні дози опромінення цей вплив значно послаблюється. Розглянуто імовірні механізми дефектоутворення, які пояснюють виявлені особливості.

Ключові слова: кремній, кисень, магнітна сприйнятливість, опромінення, термообробка 


\title{
ВЛИЯНИЕ ПРЕДВАРИТЕЛЬНОГО ОБЛУЧЕНИЯ НА МАГНИТНУЮ ВОСПРИИМЧИВОСТЬ $\mathrm{Cz}-\mathrm{Si}$, ТЕРМООБРАБОТАННОГО ПРИ 700-1000 ${ }^{\circ} \mathrm{C}$
}

\section{В. М. Цмоць, П. Г. Литовченко, Ю. В. Павловский, О. П. Литовченко, I. С. Панькив, М. М. Лучкевич}

\begin{abstract}
Аннотация. Исследовано зависимости парамагнитной составляющей магнитной восприимчивости кремния от дозы предварительного облучения быстрыми нейтронами (бн), после последующей термообработки образцов при $700-1000^{\circ} \mathrm{C}$. На основании результатов измерения магнитной восприимчивости показано, что на величину парамагнитной составляющей, которая появляется после указанных термообработок кремния, существенно влияет предварительное облучение дозами до величины порядка $10^{18} 6 \mathrm{H} / \mathrm{cm}^{2}$. При дальнейшем увеличении дозы облучения это влияние значительно ослабевает. Рассмотрено вероятные механизмы дефектообразования, которые объясняют выявленные особенности.
\end{abstract}

Ключевые слова: кремний, кислород, магнитная восприимчивость, облучение, термообработка

\section{Introduction}

Silicon remains the most convenient and best developed semiconductor to be used in physical sensors and planar structures. The major technological impurity in $\mathrm{Cz}-\mathrm{Si}$ is oxygen, which exists in oversaturated state in the crystals. During thermal treatment of silicon samples the oxygen precipitation in the nucleus centers takes place. Newly-created precipitates could serve as the impurity and point defects sinks. In this case they act as getters and clear the crystal of impurities (e.g. doping metallic atoms).

During the irradiation of silicon by neutrons disordering areas and point defects are generated in it, which could be the centers of precipitate generation. Pre-irradiation by neutrons allows not only to decrease the temperature and duration of thermal treatment, but also to control the precipitate concentration and to change their properties. The preirradiation of silicon is also known to accelerate the oxygen precipitation at subsequent thermal treatments [1]. Therefore, the study of irradiation and thermal treatment effect on oxygen precipitation is topical for a wide range of tasks, both scientific and practical ones.

We had established a correlation between the oxygen precipitation process and change of magnetic susceptibility [2]. The effect of pre-irradiation by various fast neutron doses on the thermal formation of defects in silicon and respectively on the change of its magnetic properties is discussed.

\section{Experimental results and discussion}

For the experiment the Cz-Si monocrystals grown in the $\langle 100\rangle$ direction with dissolved oxygen concentration of $8 \cdot 10^{17} \mathrm{~cm}^{-3}$, specific resistance $\sim 10 \mathrm{Ohm} \cdot \mathrm{cm}$ were used. $\mathrm{Si}$ samples were irradiated by fast neutrons on a VVR-M reactor at the temperature under $70{ }^{\circ} \mathrm{C}$ by fluencies of $10^{15}, 5 \cdot 10^{16}, 10^{18}$ and $2 \cdot 10^{19} \mathrm{fn} / \mathrm{cm}^{2}$.

Samples were produced from the same $5 \mathrm{~mm}$ thick silicon plate, cut perpendicularly to the ingot growth axis.

Before measurements the sample surface was mechanically and chemically treated. Subsequently the crystals were rinsed in distilled water.

The samples were annealed in tube heater in the air, the annealing temperature control accuracy being $\pm 2{ }^{\circ} \mathrm{C}$.

Fig. 1 shows the magnetic susceptibility vs. magnetic field intensity $(\chi(H))$ of the samples thermally treated at $700-1000{ }^{\circ} \mathrm{C}$ and pre-irradiated by different doses of fast neutrons. A shift of $\chi(H)$ dependences towards the decrease of diamagnetism is evident as compared with the original sample $\left(\chi_{S i}=-11.6 \cdot 10^{-8} \mathrm{~cm}^{3} / \mathrm{g}\right)$, which is attributed to the appearance of the MS paramagnetic component, and in the samples with maximum shift (annealed at 850 and $\left.900^{\circ} \mathrm{C}\right)$ non-linearity of $\chi(H)$ dependences is observed. The effect is enhanced with the increase of the sample pre-irradiation dose (Fig. 1, $b-d$ ).

Fig. 2 (curves 2-5) shows the magnetic susceptibility in 4 kOe field (when MS approaches saturation) vs. the annealing temperature. Obviously these dependences a similar to those obtained on the non-irradiated samples (Fig. 2, curve 1).

(C) V. M. Tsmots, P. G. Litovchenko, Yu. V. Pavlovskyy, 


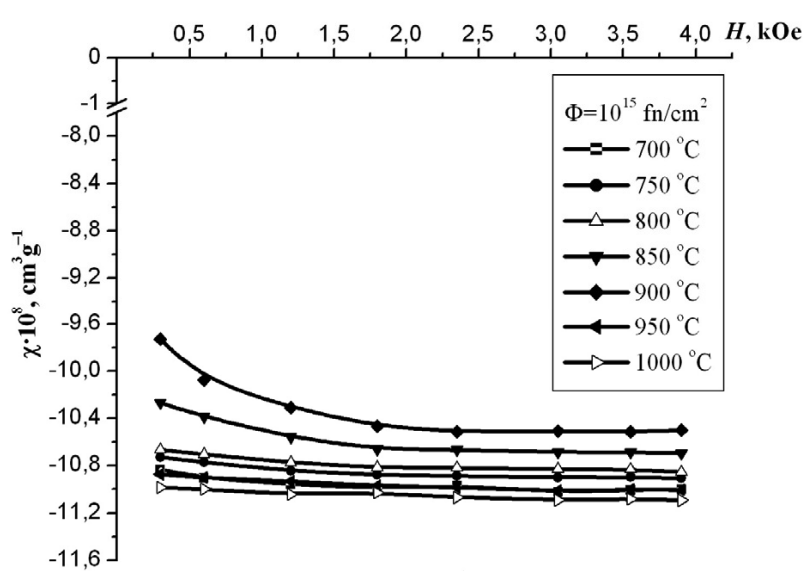

a)

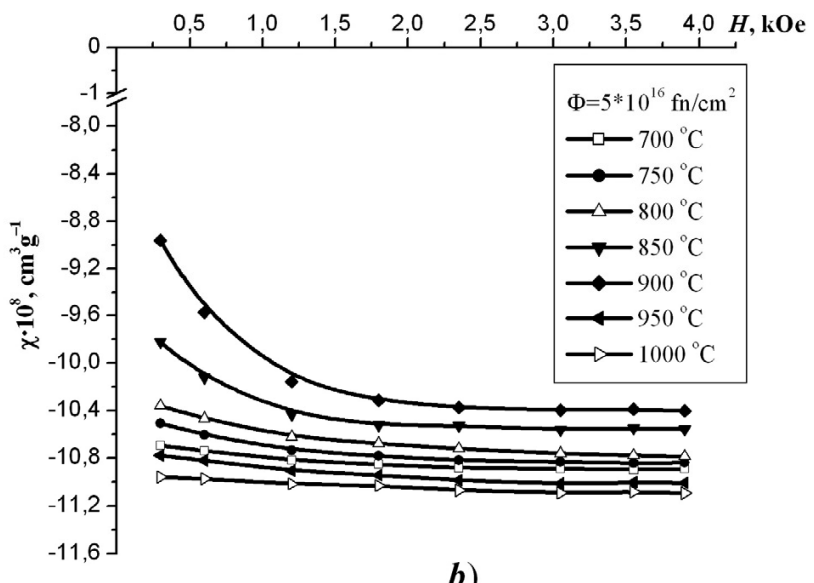

b)

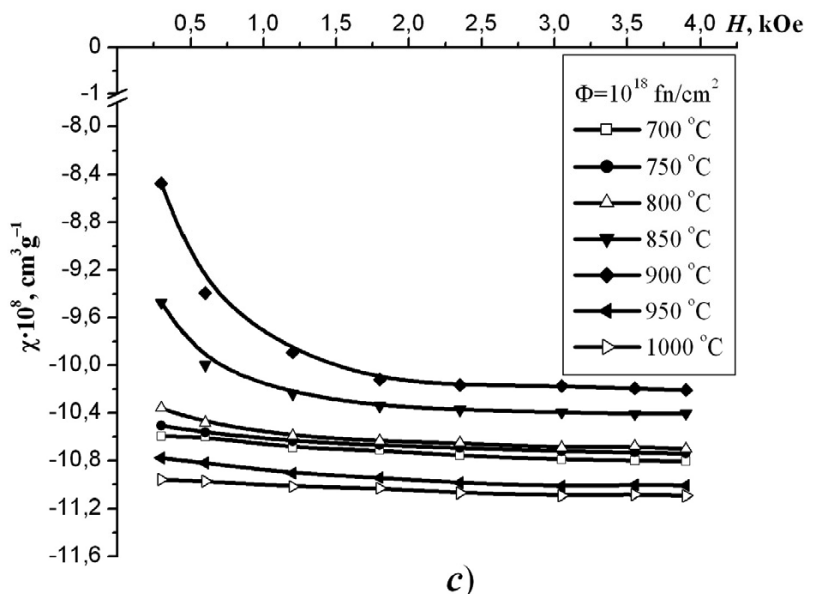

Fig. 1. Magnetic susceptibility vs. magnetic field intensity of the annealed silicon samples pre-irradiated by different fast neutron doses: $a$ ) $\left.\Phi=10^{15} \mathrm{fn} / \mathrm{cm}^{2} ; b\right) \Phi=5 \cdot 10^{16} \mathrm{fn} /$ $\mathrm{cm}^{2}$; c) $\left.\Phi=10^{18} \mathrm{fn} / \mathrm{cm}^{2} ; d\right) \Phi=2 \cdot 10^{19} \mathrm{fn} / \mathrm{cm}^{2}$

Comparing them we can see that the paramagnetic component of the magnetic susceptibility of the samples irradiated by fast neutrons increases with the increase of the radiation dose, especially in the $850-900{ }^{\circ} \mathrm{C}$ range. It leads to the conclusion that the pre-irradiation by fast neutrons causes the acceleration of thermal defect generation.

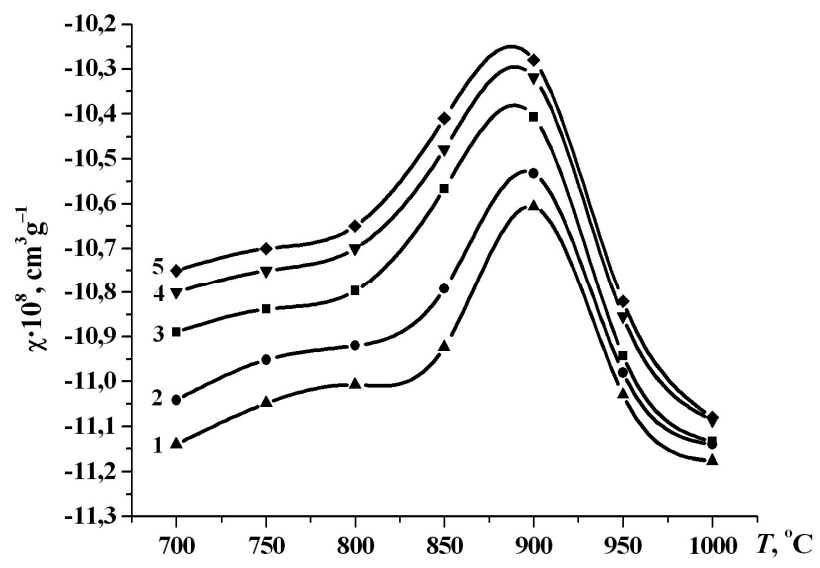

Fig. 2. Magnetic susceptibility (in 4 kOe field) vs. sample annealing temperature with pre-irradiation by different fast neutron doses: $1-$ no irradiation; $2-\Phi=10^{15} \mathrm{fn} /$ $\mathrm{cm}^{2} ; 3-\Phi=5 \cdot 10^{16} \mathrm{fn} / \mathrm{cm}^{2} ; 4-\Phi=10^{18} \mathrm{fn} / \mathrm{cm}^{2} ; 5-$ $\Phi=2 \cdot 10^{19} \mathrm{fn} / \mathrm{cm}^{2}$

In papers [3, 4], the measurements of IR-absorption of neutron-irradiated silicon show that the ratio of defect concentrations of vacancy and interstitial types is defined by the neutron flow. Thus, with the flow of up to $10^{16} \mathrm{fn} / \mathrm{cm}^{2}$ the vacancy type defects prevail, while with the flow over $5 \cdot 10^{16} \mathrm{fn} / \mathrm{cm}^{2}$ interstitial type defects begin to actively form.

It is known [5], that with the excessive concentration of thermal point defects in silicon the process of oxygen precipitation significantly changes. The data on the role of inherent interstitial silicon atoms in this process are contradictory. It has been established that with the excessive concentration of inherent interstitial atoms formed in the process of silicon ingot growth preventing their condensation into A-defects the precipitate nucleus concentration increases.

Meanwhile, the oversaturation of silicon lattice with inherent interstitial atoms under the condition of silicon oxidation [6], caused deceleration of oxygen precipitation attributed to the destruction of precipitate nuclei by these defects.

The role of vacancies accelerating precipitation of the excessive oxygen is in the opinion of [5] authors the opposite - stabilization of nuclei by forming complexes similar by their structure to donors in silicon [7].

Since the main components of radiation defects in the silicon irradiated by high-energy particles are the vacancies, the acceleration of oxygen precipitation observed in crystals irradiated by fast neutrons could be attributed to the participation of these defects and their complexes in formation and stabilization of precipitation nuclei. 
Besides, due to increase of probability of oxygen atoms being built into precipitate through creating bonds with vacancies [6], the surface energy on the silicon-precipitate matrix boundary could decrease. Decrease of the precipitate surface energy by several per cent may cause a several times increase of the precipitation rate.

Thus, deceleration of the increase of MS paramagnetic component in irradiated silicon with the increase of neutron radiation flow exceeding $10^{18}$ $\mathrm{fn} / \mathrm{cm}^{2}$ (observed at Fig. 3) could be explained by the inherent interstitial atoms participation in the oxygen precipitation process.

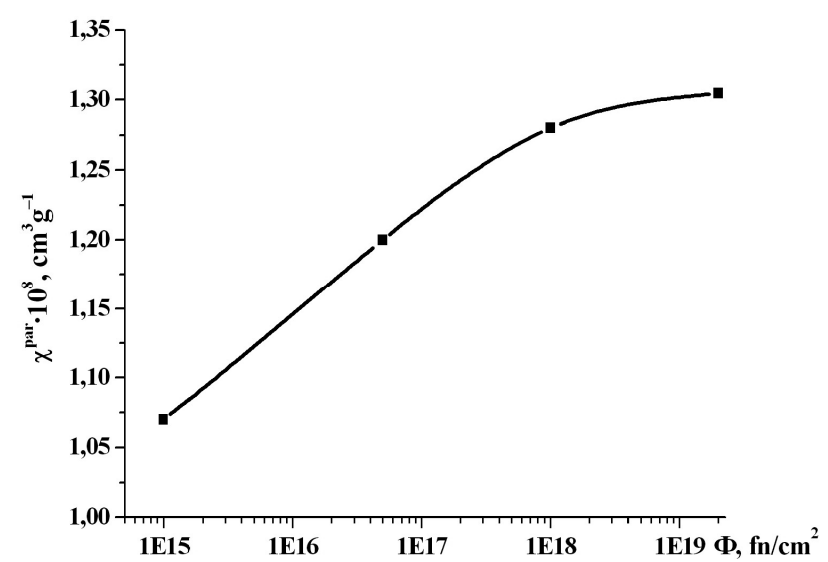

Fig. 3. Dependence of the paramagnetic component of samples after thermal treatment at $900^{\circ} \mathrm{C}$ on the pre-irradiation dose

If this effect does have place, with an increase of the neutron radiation flow from $10^{16} \mathrm{~cm}^{-2}$ to $2 \cdot 10^{19}$ $\mathrm{cm}^{-2}$ together whose vacancy type defects, which concentration is growing and which accelerate oxygen precipitation in silicon the contribution of interstitial type defects decelerating the precipitation becomes significant.

Superimposition of these two processes will lead to the fact that the value of the paramagnetic component correlating (as established in [2]) with the excessive oxygen precipitation rate will change little with the increase of the irradiation flow, which has been proved experimentally.

\section{Conclusions}

As the result of the experimental data discussion, it was shown:

1. The pre-irradiation of silicon samples with fast neutrons leads to acceleration of paramagnetic center generation in the process of thermal treatment in the $700-1000{ }^{\circ} \mathrm{C}$ temperature range.

2. The effect is significant at the irradiation doses of the order $10^{18} \mathrm{fn} / \mathrm{cm}^{2}$.

3. Further increase of the pre-irradiation dose does not lead to drastic changes of the magnetic susceptibility paramagnetic component with subsequent thermal treatment.

4. This is attributed to the fact that together with vacancy type defects accelerating the oxygen precipitation in silicon and respectively, as had been established previously in [2], the increase of paramagnetic component, the contribution of interstitial type defects decelerating the precipitation becomes significant.

\section{References}

1. Варніна В. І., Гроза А. А., Литовченко П. Г., Старчик М. І., Шматко Г. Г., Марченко Л. С., Семенюк А. К., Литовченко О. П., Вплив радіаційних дефектів на преципітацію кисню в кремнії при термообробці // УФЖ. - 2001. - Т. 46, №2. C. 205-210.

2. Литовченко П. Г., Литовченко О. П., Старчик М. І., Павловський Ю. В., Гроза А. А., Шматко Г. Г., Цмоць В. М., Петренко В. В., Кореляція між процесами преципітації кисню і поведінкою магнітної сприйнятливості в опроміненому нейтронами кремнію // НУ “Києво-Могилянська академія". Фіз. - мат. науки. - 2004. - Т. 23. - С. 63-66.

3. Гроза А. А., Хиврич В. И., Околокраевое поглощение в кремнии облучённом нейтронами и 1, 5 МэВ электронами // ФТП. - 1979. - Т. 13, №5, - C. 870-874.

4. Литовченко П. Г., Гроза А. А., Варенцов М. Д., Хиврич В. И., Томчук Л. В., Николаева Л. Г., Заславский Ю. И., Старчик М. И., Шматко Г. Г. Особенности действия быстрых и тепловых нейтронов, электронов на оптические, электрические и структурные свойства кремния // Вопр. ат. науки и техн. Сер.: Физ. радиац. поврежд. 1986. - №3. - C. 75-77.

5. De Kock A. J. R., Wijgert W. M., The Influence of Thermal Point Defects on the Precipitation of Oxygen in Dislocation Free Silicon Crystals // Appl. Phys. Lett. - 1981. - V. 38, №11. - P. 888-900.

6. Graven R. A. Semiconductor Silicon, //ed. H. R. Huff, R. J. Kriepler, J. Tamishi., The Electrochemical Society Inc. - 1985. - №4. - P. 254-258.

7. Mikkelsen J. C. Oxygen, Carbon, Hydrogen, and Nitrogen in Crystalline silicon // J. of Metals. 1985. - V. 37. - P. 51-54. 